\title{
Job Satisfaction as Predictor of Employee Engagement
}

\author{
Elvita Bellani \\ Department of Psychology \\ Hasanuddin University \\ Indonesia \\ elvita.bellani@unhas.ac.id
}

\author{
Sri Rezky Ramadhani \\ Department of Psychology \\ Hasanuddin University \\ Indonesia
}

\author{
Muhammad Tamar \\ Department of Psychology \\ Hasanuddin University \\ Indonesia
}

\begin{abstract}
The current study aims to investigate the extent of job satisfaction contribution to employee engagement. Employee engagement has been found as being important to employee productivity and organization performance. Participants were 110 employees of a private property company in Makassar, Indonesia. A self-administered questionnaire was used to measure job satisfaction and employee engagement. Simple multiple regression showed that Job satisfaction was significantly predicted employee engagement $\left(R^{2}=.561, p<.05\right)$ Additionally, multiple regression highlighted factors of job satisfaction such as operating conditions, coworkers, nature of works, and communication significantly contributed to employee engagement whereas promotion, pay benefit, and reward were found to be insignificant. These results suggest that increasing job satisfaction can potentially leverage employee engagement. However, only three out of seven factors of job satisfaction contributed significant effect to the employee engagement. Future research is needed to test whether these findings can be found in other company with the same type of business and other types of business.
\end{abstract}

Keywords - Job satisfaction; employee engagement;

\section{INTRODUCTION}

With the escalating competition in business, it is crucial to increase business competitiveness. As employees play an important role in business productivity, company should be able to make its employees engage as it will make them work optimally by devoting their resources to company. Engaged employee is characterized by satisfied employee combined with dedication, vigour and absorption [1]. Engaged employee has an emotional attachment to the company which result in willingness to improve their productivity, innovation and retention [1][2]. This form of engagement will be profitable to the company as well as beneficial to employees [3]. For company, employee engagement positively correlates with employee performance [4], and thus result in increasing organizational growth and performance [4][5]. At individual level, employee engagement is positively correlates with employee satisfaction at work, and employees experience on job [5]. Furthermore, employee engagement is also positively correlate with employee's health, and positive emotion [6].
According to Social Exchange Theory, employee who receive economic and socioemotional resources will feel as he/she is indebted to company and thus willing to improve his/her performance by increasing engagement to company [3], [5] [7]. In addition, fulfilment of employee economic and socioemotional needs will increase employee job satisfaction which result in increasing positive attitude toward company and result in employee willingness to boost his/her performance [7]. Accordingly, job satisfaction is regarded as driver to employee engagement [8],[9],[10]. However, satisfied employee does not automatically lead to engagement. Employee can be satisfied with economics and socioemotional resources received, yet not significantly contributed to company performance [8]. Hence, whether job satisfaction can predict employee engagement remain inconclusive.

The purpose of this present study is to examine to what extend do job satisfaction can predict employee engagement. Because job satisfaction does not necessarily leads to engagement, this present study also aims to analyze which aspect of job satisfaction can lead to employee engagement.

\section{LITERATURE REVIEW}

\section{A. Employee Engagement}

There are several perspectives in employee engagement. Kahn (p.64) proposes that employee engagement as "the harshening organization members' themselves to their work roles; in engagement, people employ and express themselves physically, cognitively, and emotionally" [3]. Schaufeli (p.74) explains that engagement as "a positive, fulfilling, workrelated state of mind is characterized by vigor, dedication, and absorption"[1]. Accordingly, vigor is described as an amount of energy produced in the work that can be manifested in the form of mental resiliency and persistent in the face of adversity. Dedication as feeling of meaning, enthusiasm, inspiration, pride and challenge in work, and absorption as deep concentration and interest, drowning in work, time 
passes so fast and the individual is difficult to get away from work so that forget everything else around it. Alternatively, engaged employee is characterized by energy, involvement and efficacy in performing their job [11]. To conclude, engagement can be seen as employee's physical, cognitive and emotional availability which result in vigor, dedication, and absorption in performing their job roles. As a consequence, engaged employee will devote themselves in performing their job and thus result in meaningful contribution to company.

Employee will be engaged with their work if they are psychologically available, and considered their job as meaningful and safety [3]. It can be reached when people receive supportive resources from their organization. These resources includes socioemotional resources as reward from the job [5], also job resources that will reduce their job demands [1][12]. When employee's socio emotional needs are fulfilled by organization, employees are willing to go extra mile to achieve organizational goals [7]. As a consequence, it will give positive attitude toward organization [5] and a fulfilling and positive work-related state of mind that lead to motivation for attaining the work goal [3].

\section{B. Job Satisfaction}

Spector [13] proposes that job satisfaction is the extent to which employee like their job or aspects of their job. When employees perceive that their job fulfill their needs, values and personal characteristics, their job satisfaction will increase and thus develop individual positive attitudes toward work and its environment [14].

Job satisfaction can be measured globally, which is, the extent to which individuals are satisfied or dissatisfied with their overall job. The second approach is the facet approach, where job satisfaction is broken down into aspects or facets that are used as the basis for identifying aspects that need to be developed in order to improve employee satisfaction [13].

Spector [13] list facets of job satisfaction as follows: Pay (i.e. to what expend employee is satisfied with salary received), promotion (i.e. to what extend employee is satisfied with promotion policy and opportunity), supervision (i.e. to what extend employee is satisfied with his/her supervisor, as to whether the supervisor is warm, friendly and appreciative), benefit (i.e. to what extend employee is satisfied with the benefit given), rewards (i.e. to what expend employee is satisfied with appreciation, and respect given as result of his work), operating condition (i.e. to what extend employee is satisfied with procedure, rules and work load), co-workers (i.e. to what extend employee is satisfied with relationship with his co-workers), nature of works (i.e. to what extend employee is satisfied with the job, as to whether the job bring joy or not), and communication ( to what extend task and obligation are well communicated in organization)
Job satisfaction result in positive outcomes. It is reported that job satisfaction is correlated with positive business outcomes, i.e. customer loyalty; business profitability, and productivity, decrease in employee turnover, and safety outcomes [2]. Arguably, job satisfaction can provide positive attitude to organization as well as motivation to work [7][15]. However, Herzberg [15] differentiate between motivation factors and hygiene factors. Motivation factors include recognition, work itself, responsibility and advancement. Fulfillment of these factors will facilitate motivation. In contrast, hygiene factors are policy administration, supervision, salary, interpersonal relations, and working conditions of which fulfillment of these factor will not lead to motivation but can prevent employees from dissatisfaction.

\section{Job Satisfaction and Employee Engagement}

Research about relation between job satisfaction and employee engagement has been intensively done. However, the direction of relationship remain inconclusive [16]. Some studies argue that job satisfaction is an positive outcome of employee engagement. These studies measure job satisfaction with the global approach [5][17]. In contrast, when job satisfaction is examined by facet approach, job satisfaction is an antecedent of employee engagement, in which individual satisfaction with his or her work will increase the individual's engagement with his or her work and company [8]-[10].

This present study aims to examine job satisfaction as predictor of employee engagement using facet approach. It is expected that job satisfaction predicts employee engagement. According to Social Exchange Theory, employee who receive economic and socioemotional reward from their organization will develop positive attitude toward organization and thus will be willing to devote themselves to the organization[5]. In addition, job satisfaction deals with emotion related to what extends employee's needs are fulfilled or not [18]. When individual needs are fulfilled, employees will be motivated to be engaged to their job and organization, as it will gratify their need [16]

\section{METHODS}

\section{A. Participants}

Participants were 110 employees working at a property management company in Indonesia. Most of the participants are men $(76 \%)$, aged $26-30$ years old $(26 \%)$, are in staff position $(87.27 \%)$, with salary range from 3 million to 5 million rupiahs $(42.73 \%)$. Participants had been in their current job for at least a year.

\section{B. Procedure}

Participation in this study was voluntary. Informs consent letter was included in questionnaire explaining the purpose of 
this study, their voluntary participation and assurance about participants anonymity and confidentiality response. Questionnaire were distributed to all the employees $(n=120)$ but only 110 were returned representing $91 \%$ of response rate.

\section{Measures}

\section{Employee Engagement}

Employee engagement were measured using adapted UWES scale by Schaufeli \& Bakker [19]. Firstly, the scale was translated using back translation procedure. Next, translated scale were pre-tested to measure validity and reliability. Using Confirmatory Factor Analysis two item were deleted, leaving only 15 items. Internal consistency reliability was .916.

\section{Job Satisfaction}

Job Satisfaction were measured using adapted Job Satisfaction Survey by Spector [13]. The scale was translated using back translation procedures. Then, the scale was pretested to measure validity and reliability. By Confirmatory Factor Analysis 5 items were found to be invalid and thus deleted, leaving only 31 items from the 36 items original scale. Internal consistency reliability was .86 .

\section{RESULT}

TABLE I. DESCRIPTIVE STATISTICS

Employee Engagement

\begin{tabular}{cccc}
\hline & $\mathrm{N}$ & Mean & $\sigma^{2}$ \\
\hline Employee Engagement & 110 & 48.08 & 10.66 \\
\hline
\end{tabular}

Job Satisfaction

\begin{tabular}{cccc}
\hline $\begin{array}{c}\text { Facets of } \\
\text { Job Satisfaction }\end{array}$ & $\mathrm{N}$ & Mean & $\sigma^{2}$ \\
\hline Pay & 110 & 7.67 & 1.9 \\
Promotion & 110 & 4.7 & 1.1 \\
Supervision & 110 & 9.4 & 1.53 \\
Benefits & 110 & 9.15 & 2.06 \\
Rewards & 110 & 8.2 & 1.34 \\
Operating Conditions & 110 & 5.04 & 1.28 \\
Nature OF Works & 110 & 9.19 & 1.28 \\
Communication & 110 & 8.79 & 1.48
\end{tabular}

TABLE 2. SUMMARY OF REGRESSION ANALYSIS FOR JOB SATISFACTION FACTORS PREDICTING EMPLOYEE ENGAGEMENT

\begin{tabular}{|c|c|c|c|c|c|c|}
\hline \multicolumn{7}{|c|}{ Coefficients } \\
\hline & & \multicolumn{2}{|c|}{$\begin{array}{c}\text { Unstandardized } \\
\text { Coefficients }\end{array}$} & \multirow{2}{*}{$\begin{array}{c}\text { Standardized } \\
\text { Coefficients } \\
\text { Beta }\end{array}$} & \multirow[b]{2}{*}{$\mathrm{t}$} & \multirow[b]{2}{*}{ Sig. } \\
\hline \multicolumn{2}{|c|}{ Model } & $\mathrm{B}$ & Std. Error & & & \\
\hline 1 & (Constant) & 6.672 & 3.411 & & 1.956 & .053 \\
\hline & Promotion & .553 & .428 & .110 & 1.294 & .199 \\
\hline & Pay & -.095 & .295 & -.031 & -.322 & .748 \\
\hline & Supervision & .248 & .368 & .065 & .672 & .503 \\
\hline & Benefit & .046 & .291 & .016 & .157 & .876 \\
\hline & Rewards & .332 & .428 & .076 & .776 & .440 \\
\hline & Operating conditions & 1.031 & .373 & .224 & 2.760 & .007 \\
\hline & Co-workers & -.771 & .439 & -.158 & -1.757 & .082 \\
\hline & Nature of works & 2.117 & .417 & .462 & 5.072 & .000 \\
\hline & communications & .948 & .410 & .239 & 2.313 & .023 \\
\hline & $\mathrm{R}^{2}$ & .561 & & & & \\
\hline & Adjusted $\mathrm{R}^{2}$ & .522 & & & & \\
\hline & $\mathrm{F}$ & 14.22 & & & & $.000^{\mathrm{b}}$ \\
\hline
\end{tabular}

Multiple Regression Analysis was performed with facets of job satisfaction as predictors variables and engagement as criterion variable. Facets of job satisfaction include promotion, pay, supervision, benefit, rewards, operating conditions, coworkers, nature of works, and communications. A significant regression equation was found $(\mathrm{F}(9,100)=14.220, p<.05)$, with an $\mathrm{R}^{2}$ of .561. Only operating conditions, nature of works, and communication are significant predictor to employee engagement. Participants predicted employee engagement is equal to $6.672+1.031$ (Operating conditions) + 
2.117 (nature of works) +.948 (communication). Participants engagement score increase by 1.031 for each point of operating condition and 2.117 points increase for each point of nature of works and .948 increase of each point communication

\section{DISCUSSION}

This study aims to understand to what extend facets of job satisfaction predicts employee engagement. Multiple regression analysis conducted showed facets of job satisfaction as significant predictors of employee engagement. The result is in line with previous research that show job satisfaction as driver and antecedent of employee engagement [8]-[10]. Satisfaction with the fulfillment of economic and socioemotional needs will increase employees positive attitude toward their job and organization also their willingness to contribute more to organization, and thus will increase engagement [5][3][13].

However, only operating condition can serve as predictors of employee engagement. This result is contradicted with previous research which propose that promotion, pay, supervision, benefit, coworkers, and communication as significant predictors of employee engagement [8] in addition to job, recognition, cooperation, fair treatment, company policies, and team spirit [9]. These contradicting results show that while there have been many research concluding that job satisfaction serve as significant employee engagement predictors, aspects of job satisfaction which contribute to employee engagement remain diverse across population.

The result of this studies shows that satisfaction in nature of works, communication and working conditions are significantly contribute to employee engagement. These three facets are related to the job itself. Arguably, satisfaction with the job itself drives intrinsic motivation. Intrinsically motivated employees are triggered to work and even to go extra mile because the job itself satisfy their needs, and thus make them happy to do the job [21]. In line to Schaufeli [20] intrinsically motivated employees are more likely to be engaged to his organization.

In contrast, aspects related to economic reward, supervision, co-workers, and promotion are not significantly predict employee engagement. These aspects are related to instrumental reward gain from the job and thus yield external motivation [22]. In fact, Herzberg [15] suggests, that economic reward, supervision and co-workers are hygiene factors which cannot deliver motivation and only serve to decrease dissatisfaction. When these hygiene aspects are fulfilled, employees are less likely to be dissatisfied with their job, but it does not make them motivated to do their job.

To be engaged, employees must be intrinsically motivated [20]. The job that can drive intrinsic motivation are the job that provide sense of choice, sense of accomplishment, sense of competence, and sense of meaningfulness [23]. In line with
Cartwright and Holmes [24], and Kahn [3], to be engaged, employee must consider that their job and their presence are meaningful. This can be reached when the job provides sense of efficacy, sense of self-worth and justification for doing such action [24].

Internally motivated employees consider their job and their contribution as meaningful. They also believe that they have competency to the job and feel sense of accomplishment when they managed to finish their job. Hence, the job itself as a source of satisfaction, not the instrumental reward gain from the job such as payment, benefit, and promotion. Internally motivated employee thinks that the job itself is rewarding. Consequently, they are motivated to devote themselves to their job and thus are more likely to be engaged.

To conclude, the result of this study shows that job satisfaction is a significant predictor to employee engagement. However only facets related to the job itself, i.e. communication, nature of works, and working conditions can predict engagement. We argue because only these facets of job satisfaction relate to internal motivation. Nevertheless, this result is not supported by similar previous research conducted before [8][9], and therefore this result need to be interpreted with caution. Further research to examine the relation between aspect of job satisfaction, internal motivation need to be conducted to understand their relationship.

\section{CONCLUSION}

Nowadays, with tremendous increase of competition in business, it is very important to have engaged employees, as it will escalate organization performance. Engaged employee is highly involved with his/her organization, and enthusiastic to strive for organization's sake [2][11]. This present study suggests that job satisfaction is significant predictor to employee engagement. However, not all facets of job satisfaction are significant predictors to employee engagement. Only operating conditions, nature of works and communication that drive employee engagement. In contrast, pay, supervision, benefit, co-workers, promotion, and reward are not significantly contributing to employee engagement. Only aspects that related to the job itself are significantly contributed to employee engagement, in contrast to aspects which are rewarded as consequences from the job. A possible explanation for this might be that to be engaged, employees need to be satisfied with aspects that drive internal motivation. Internal motivation can be obtained from the job which is meaningful [21][3] and rewarding.

\section{REFERENCES}

[1] W.B. Schaufeli and A.B. Bakker "Job demands, job resources, and their relationship with burnout and engagement: A multi-sample study." Journal of organizational Behavior, vol. 25, pp. 293-315. March 2004

[2] J.K. Harter, F.L. Schmidt and T.L. Hayes. "Business-unit-level relationship between employee satisfaction, employee engagement, and business outcomes: a meta-analysis." Journal 
of Applied Psychology, vol. 87, pp. 268-279, April 2002

[3] W.A. Kahn (1990). "Psychological conditions of personal engagement and disengagement at work." Academy of Management Journal, vol. 33(4), 692-724. Dec 1990

[4] S.M. Kompaso and M.S. Sridevi, M. "Employee engagement: The key to improving performance." International Journal of Business and Management, vol 5, pp. 89-96, Dec 2010

[5] A.M. Saks "Antecedents and consequences of employee engagement." Journal of Managerial Psychology, vol. 21, pp. 600-619. 2006

[6] S. Sonnentag, S. "Recovery, work engagement, and proactive behavior: a new look at the interface between nonwork and work." Journal of applied psychology, vol.88, pp. 518-28. Jun 2003

[7] R. Cropanzano, R and M.S. Mitchell. "Social exchange theory: An interdisciplinary review." Journal of Management, vol.3, pp. 874-900. Dec 2005

[8] A. Garg, A and V. Kumar. "A study of employee engagement in pharmaceutical sector." International Journal of Research in IT and Management, vol. 2, pp. 85-98, May 2012

[9] S. Abraham. (2012). "Job Satisfaction as an Antecedent to Employee Engagement." SIES Journal of Management, vol. 8, pp. 27-36, Sept 2012

[10] D.R. Avery, P.F. McKay, and D.C. Wilson. "Engaging the aging workforce: the relationship between perceived age similarity, satisfaction with coworkers, and employee engagement." Journal of Applied Psychology, vol. 92 pp.1542-46, Nov 2007

[11] C. Maslach, "What have we learned about burnout and health?" Psychology \& health, vol. 16, pp. 607-611, Sept 2001

[12] A.B Bakker and E. Demerouti, E. (2014). "Job demandsresources theory." Wellbeing. Vol. 3 pp.1-28, Feb 2014

[13] P.E. Spector. Job satisfaction: Application, assessment, causes, and consequences. Thousand Oaks, California: Sage Publication, Inc., 1997 pp.1-11.

[14] M.C. Ellickson, \& K. Logsdon. "Determinants of job satisfaction of municipal government employees." Personnel Administration, vol. 3, pp.343-358, Dec 2001

[15] F. Herzberg, B. Mausner and B. Snyderman. The motivation to work New York: John Wiley and Son 1959.

[16] B.A. Rayton, B. A and Z.Y. Yalabik. "Work engagement, psychological contract breach and job satisfaction." The International Journal of Human Resource Management, vol. 25 , pp. 2382-2400, Jan, 2014

[17] R. Høigaard, R. Giske, and K. Sundsli. "Newly qualified teachers' work engagement and teacher efficacy influences on job satisfaction, burnout, and the intention to quit." European Journal of Teacher Education, vol. 35, pp. 347-357, Feb 2011

[18] B.L. Rich, J.A. Lepine, and E.R Crawford, E.R. 'Job Engagement: Antecedents and Effects on Job Performance,' Academy of Management Journal, vol. 53, pp. 617- 635. Jun 2010

[19] W. Schaufeli, and A. Bakker. "UWES-Utrecht work engagement scale: Preliminary test manual." Internet : http://www.wilmarschaufeli.nl/publications/Schaufeli/Test $\% 20 \mathrm{M}$ anuals/Test manual UWES English.pdf Dec. 2004 [Nov. 4 2017]

[20] W. Schaufeli, and M. Salanova, M. "Work engagement." Managing social and ethical issues in organizations, Connecticut: Information Age Publishing Inc., 2007 pp.135-177. 2007

[21] J.P. Meyer and M. Gagne. "Employee engagement from a selfdetermination theory perspective." In Industrial and Organizational Psychology, vol.1(1), pp.60-62. 2008
[22] T.M. Amabile, (1993). "Motivational synergy: Toward new conceptualizations of intrinsic and extrinsic motivation in the workplace." Human resource management review, vol.3 pp.185201. 1993

[23] K.W. Thomas, Intrinsic motivation at work: What really drives employee engagement. San Fransisco: Berrett-Koehler Publishers, 2009

[24] S. Cartwright, S and N. Holmes, N. "The meaning of work: The challenge of regaining employee engagement and reducing cynicism." Human Resource Management Review, vol. 16, pp. 199-208, Jun 2006 